\title{
Frequency of the Tay-Sachs disease splice and insertion mutations in the UK Ashkenazi Jewish population
}

\author{
Eleanor C Landels, Ian H Ellis, Anthony H Fensom, Peter M Green, Martin Bobrow
}

\begin{abstract}
Tay-Sachs disease is a lethal neurodegenerative disorder caused by deficiency of the lysosomal enzyme $\beta$-hexosaminidase $A$ and inherited in an autosomal recessive fashion; carriers of the disease are $\mathbf{1 0}$ times more frequent in the Ashkenazi Jewish community than in the general population. Over $\mathbf{9 0 \%}$ of North American Ashkenazi carriers tested have been shown to have either a splice site mutation at the boundary of exon 12 and intron 12 in the $\beta$-hexosaminidase $\alpha$ subunit gene, or a 4 base pair insertion in exon 11. We describe simple assays involving amplification of DNA across these two mutation sites by polymerase chain reaction and the results of screening 75 subjects are given.

The frequencies of the splice and insert mutations in 41 UK Ashkenazi carriers ( $20 \%$ to $80 \%$, respectively) were similar to those found in the North American community. Twelve Ashkenazi subjects classified as non-carriers on enzyme assay were found to be negative for both mutations tested. All Ashkenazi carriers tested (both obligate carriers and those picked up by population screening) had either the splice or insert mutations; in contrast to this, only $21 \%$ of the non-Ashkenazi carriers had one or other of these mutations.

It is concluded that within the carrier screening programmes for the Ashkenazi community, assays for the splice and insert mutations, together with an assay recently described for a mutation causing the rarer adult onset form of the disease, will prove useful as confirmatory tests for subjects who give positive or borderline results when screened on enzyme assay.
\end{abstract}

Tay-Sachs disease (TSD), one of the most severe forms of the $\mathbf{G M}_{2}$-gangliosidoses, is an incurable

Paediatric Research Unit, Division of Medical and Molecular Genetics, United Medical and Dental Schools of Guy's and St Thomas's Hospitals, 8th Floor, Guy's Hospital Tower, London SE1 9RT.

E C Landels, I H Ellis, A H Fensom, P M Green, M Bobrow Correspondence to Dr Landels.

Received for publication 27 July 1990.

Revised version accepted for publication 20 September 1990. neurodegenerative disorder inherited in an autosomal recessive fashion. Damage to the nervous system is caused by accumulation of ganglioside $\mathrm{GM}_{2}$, the metabolism of which is blocked because of deficient activity of the lysosomal enzyme $\beta$-hexosaminidase $A$ (Hex A). The cause of TSD is mutation in the gene, located on chromosome 15, for the $\alpha$ subunit of $\mathrm{Hex}$ A. Carriers of the TSD gene, who have reduced Hex A activity, are estimated to have a frequency of $1 / 167$ in the general population. ${ }^{1}$ However, in the Ashkenazi Jewish population TSD carriers are approximately 10 times more frequent and so carrier screening programmes, based on measuring Hex A activity in serum or leucocyte samples, ${ }^{2}$ have been made available to Ashkenazi Jewish communities, with the aim of reducing the incidence of TSD births.

The hexosaminidase $\alpha$ subunit gene has been cloned $^{34}$ and several mutations causing various $\mathrm{GM}_{2}-$ gangliosidoses have been characterised. ${ }^{5}$ In the Ashkenazi community there appear to be two mutations accounting for over $90 \%$ of TSD carriers. A splice junction mutation ${ }^{6-8}$ of a $G$ to $C$ transition in the first nucleotide of intron 12, fortuitously creating a DdeI site, was present in 11 of 40 obligate TSD carriers. ${ }^{67}$ The more common mutation, found in 14 of 20 obligate TSD carriers, ${ }^{9}$ is a 4 bp insertion in exon 11. Assays have been described for these two mutations, based on the polymerase chain reaction (PCR), which involve radiolabelling during DNA amplification ${ }^{7}$ or the use of radiolabelled oligonucleotides of mutant or normal sequences to probe patient DNA. $^{69}$ More recently, Triggs-Raine et al ${ }^{10}$ have used amplification of DNA by PCR followed by restriction enzyme digestion to assess the incidence of the splice and insert mutations in the North American Ashkenazim. They also screened this population for the $\mathrm{Gly}^{269}$ to Ser mutation in exon 7 which causes adult onset $\mathrm{GM}_{2}$-gangliosidosis. ${ }^{11}{ }^{12}$

We have independently developed similar assays for carriers of the splice and insert mutations, avoiding radioisotope labelling, based on amplification of DNA by PCR followed by digestion with DdeI for detection of the splice mutation (restriction enzyme digestion is not necessary to detect the insert mutation.) DNA fragments were then separated by electrophoresis and viewed directly under UV light. Here we present data on the frequency of these two mutations in the UK Ashkenazi community. We have 
tested 75 subjects, including both Jewish and nonJewish obligate carriers for TSD, and subjects picked up by population screening programmes whose carrier status has been determined by enzyme assay.

\section{Materials and methods}

Population screening was based on measuring percentage Hex A in serum and leucocyte samples. The assay was essentially as described by $\mathrm{Kaback}^{2}$ but adapted to be carried out on a centrifugal analyser. ${ }^{13}$

\section{DNA AMPLIFICATION}

Approximately $100 \mathrm{ng}$ of genomic DNA, isolated by phenol-chloroform extraction using a 340A Nucleic Acid Extracter (Applied Biosystems) from blood samples (whole EDTA blood or white blood cell pellets, stored at $-20^{\circ} \mathrm{C}$ ), were amplified by the PCR method. ${ }^{14}$ The oligonucleotide primer sequences used to amplify the region of the splice mutation were as published previously. ${ }^{6}$ For the region of the insertion mutation we designed primer sequences based on the published cDNA sequence': TS1-5': 5'-TTCCGGGCCCTTCTCTCTGCC-3' and TS1-3': 5'-TTCAAATGCCAGGGGTTCCAC-3'. The reaction mix contained 2.5 units of Taq polymerase (Amplitaq, Cetus), $0.5 \mathrm{mmol} / 1 \mathrm{dNTPs}, 300 \mathrm{ng}$ of each primer, 67 $\mathrm{mmol} / \mathrm{l}$ Tris- $\mathrm{HCl}, \mathrm{pH} 8.8,16.6 \mathrm{mmol} / 1\left(\mathrm{NH}_{4}\right)_{2} \mathrm{SO}_{4}$, $6.7 \mathrm{mmol} / \mathrm{l} \mathrm{MgCl}_{2}$, and $170 \mu \mathrm{g} / \mathrm{ml}$ bovine serum albumin.

The reaction was carried out in a Perkin-Elmer Cetus thermal cycler for 35 cycles of one minute at $93^{\circ} \mathrm{C}$, three minutes at $70^{\circ} \mathrm{C}$. For detection of the splice mutation, products of the PCR were then digested with $D d e \mathrm{I}$ at $37^{\circ} \mathrm{C}$ for one hour. The products of reactions were electrophoresed in $12 \%$ polyacrylamide minigels containing ethidium bromide for approximately 45 minutes at $80 \mathrm{~mA}$ current, and viewed under UV light.

\section{Results}

The results of the splice mutation assay are shown in fig 1 . Track 1 shows the $135 b^{6}$ DNA band amplified by PCR. After digestion with DdeI, non-carrier DNA is reduced in size to a $120 \mathrm{bp}$ fragment and two smaller fragments which are not seen as they run off the gel, shown in track 3. Carriers of the splice mutation have an extra $D d e I$ site and so after digestion have four DNA fragments, $85 \mathrm{bp}, 35 \mathrm{p}$, and the two smaller fragments, of which only the 85 bp fragment is seen (track 2). As well as the 85 bp fragment, the unmutated DNA of the normal allele has also been amplified and on digestion with DdeI gives the $120 \mathrm{bp}$ fragment (also visible in track 2).

Detection of the 4 bp insert mutation is also

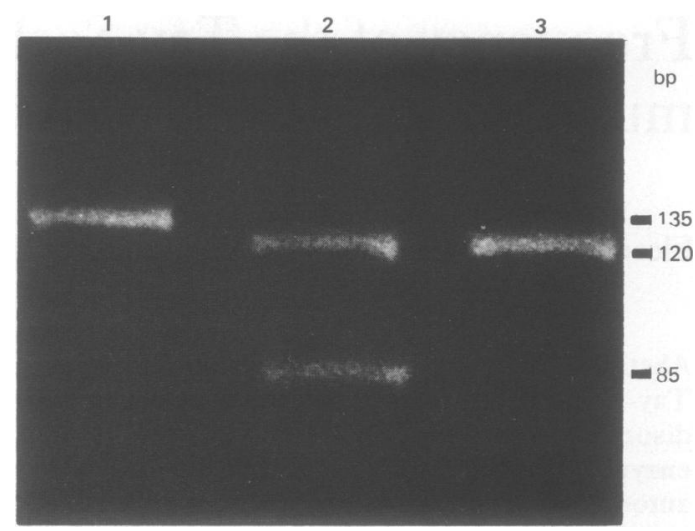

Figure 1 Detection of the splice site mutation: normal and heterozygote DNA patterns after amplification by PCR and $D$ deI digestion. (1) Amplified DNA (before DdeI digestion), (2)heterozygote DNA, (3) normal DNA.

straightforward. Fig 2, track 1 shows the 96 bp DNA amplified in a non-carrier; heterozygotes for the insert will have both a $96 \mathrm{bp}$ band and one of $100 \mathrm{bp}$ (fig 2, track 2). The $4 \mathrm{bp}$ difference is resolvable in a $12 \%$ polyacrylamide gel. There is also a further band which is probably a heteroduplex of normal and mutated DNA. ${ }^{15}$ The two types of DNA will pair exactly except for the $4 \mathrm{bp}$ insert which probably loops out, causing the heteroduplex to migrate anomalously. This 'hybrid' band is reproducible and

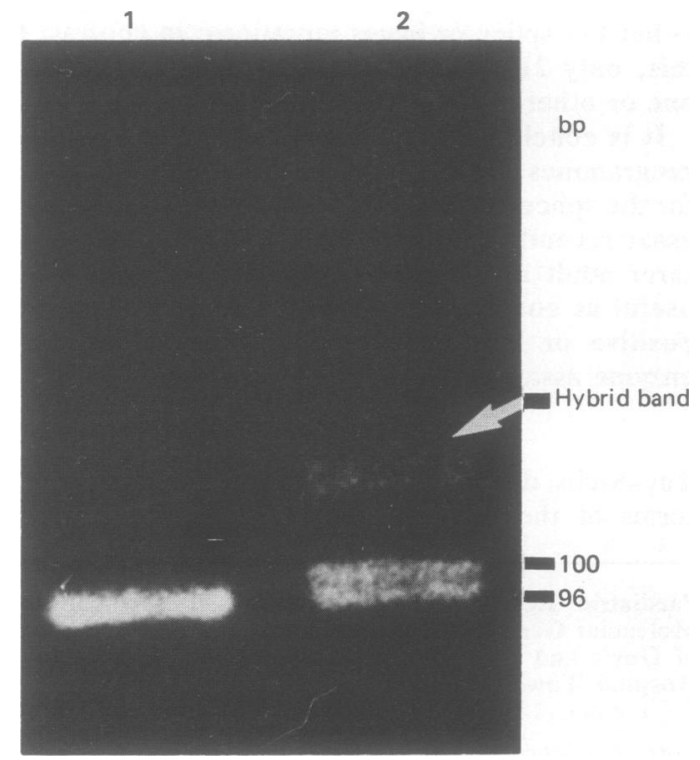

Figure 2 Detection of the 4 bp insertion mutation: normal and heterozygote DNA patterns after amplification by PCR. (1) Normal DNA, (2) heterozygote DNA. 
Results of screening 75 subjects for the splice and insert mutations.

\begin{tabular}{|c|c|c|c|}
\hline & & Splice & Insert \\
\hline & No tested & No (\%) & No (\%) \\
\hline $\begin{array}{l}\text { Obligate carriers, Jewish } \\
\text { Enzyme screened } \\
\text { Total }\end{array}$ & $\begin{array}{l}15 \\
26 \\
41\end{array}$ & $\begin{array}{l}5 \\
3 \\
8(19 \cdot 5)\end{array}$ & $\begin{array}{l}10 \\
23 \\
33(80 \cdot 5)\end{array}$ \\
\hline Non-carriers, Jewish & 12 & $\mathbf{0}$ & 0 \\
\hline $\begin{array}{l}\text { Obligate carriers, non-Jewish } \\
\text { Enzyme screened } \\
\text { Total }\end{array}$ & $\begin{array}{r}16 \\
3 \\
19\end{array}$ & $\begin{array}{l}0 \\
1 \\
1(5 \cdot 3)\end{array}$ & $\begin{array}{l}3 \\
0 \\
3(15 \cdot 8)\end{array}$ \\
\hline $\begin{array}{l}\text { Inconclusive (on enzyme } \\
\text { screening) } \\
\text { Jewish } \\
\text { Non-Jewish }\end{array}$ & $\begin{array}{l}2 \\
1\end{array}$ & $\begin{array}{l}0 \\
0\end{array}$ & $\begin{array}{l}0 \\
0\end{array}$ \\
\hline
\end{tabular}

makes detection of heterozygotes for the insert mutation very easy. The results of screening various subjects using these two assays are shown in the table.

\section{Discussion}

The frequencies of the splice and insert mutations among UK Ashkenazi TSD carriers tested so far $(20 \%$ and $80 \%$ respectively) are similar to those found in the North American community. ${ }^{6} 7910$ In the most recent study, ${ }^{10}$ TSD carriers picked up by population screening were also tested for the Gly ${ }^{269}$ to Ser mutation in exon 7 of the Hex A $\alpha$ subunit gene, which causes adult $\mathrm{GM}_{2}$-gangliosidosis; five out of 216 carriers had this mutation. We studied 26 Ashkenazi carriers picked up through population screening. If the frequency of the exon 7 mutation in the UK Ashkenazi population is similar to that in the North American Ashkenazim, we would only expect to find 0.6 carriers to be negative for both the splice and insert mutations; thus it is not significant that none was found.

Twelve Ashkenazi Jewish subjects classified previously by enzyme screening as non-carriers were negative for both the splice and the insert mutations. Three subjects, two of whom were Ashkenazi, who repeatedly gave borderline results on enzyme assay, were also negative for both mutations. Work is in progress to test these subjects for the exon 7 mutation.

In the study of North American Ashkenazim, ${ }^{10} 39$ of 216 carriers picked up by population screening were found not to carry the splice, insert, or exon 7 mutations, an apparent false positive rate of $18 \%$. Assuming a similar false positive rate, we would expect to have found four or five of the 26 carriers picked up by population screening to be negative for both the splice and insert mutations; we found none. We feel this almost certainly reflects differences in the enzyme assays of different testing laboratories.
All 41 Ashkenazi carriers (as classified by enzyme assay of serum and leucocyte samples) tested were positive either for the splice or insert mutations. In contrast to this, only $21 \%$ of the 19 non-Jewish carriers tested proved positive for one or other of these mutations; $5.3 \%$ had the splice mutation and $15 \cdot 8 \%$ had the insert. The remaining $79 \%$ presumably carry unknown mutations.

Although in this study $100 \%$ of Ashkenazi carriers tested have had either the splice or insert mutation, other workers have found an Ashkenazi TSD patient who was heterozygous for the insert and an unknown mutation. ${ }^{9}$ It is thought that Hex A $\alpha$ subunit mutations other than the splice and insert occur at the same low frequency in Ashkenazim as in the general population. ${ }^{16}$ Thus, while it can be envisaged that these assays, together with the assay for the exon 7 mutation, ${ }^{10}$ will be useful in addition to the enzyme assay, if used alone for carrier screening within the Ashkenazi community approximately $2 \%$ of carriers will be missed.

At present the need to extract DNA before PCR amplification adds considerably to the time and cost of these assays. We are further developing the assays to allow amplification by PCR directly on DNA released from various tissues, avoiding the DNA extraction step, as has been done for blood and cells collected using clinical swabs. ${ }^{17}$ Another way of reducing the cost of the assays may be to combine them, so that the regions of both the insert and splice mutations are amplified in the same reaction mixture; this should be possible since the same temperature cycles are used for both sets of primers. The resulting products, or an aliquot of them, would then be digested with DdeI to show the splice mutation. A disadvantage is that the band patterns would be more complex but the convenience of testing for both mutations at the same time should outweigh this.

In conclusion, an optimum strategy might be to screen on the basis of serum Hex A levels, using PCR assays to confirm all borderline and positive results, with leucocyte enzyme assays held in reserve for problematic cases.

We are grateful to Roland Roberts for helpful discussions and primer sequence design skills, Simon Dear and Suzanne Clark for help with DNA extraction, Adrienne Knight for help in preparing the manuscript, and to the British Tay-Sachs Foundation for generous financial support.

1 Sandhoff K, Conzelmann E, Neufeld E, Kaback M, Suzuki K. The $G_{M 2}$ gangliosidoses. In: Scriver CR, Beaudet AL, Sly WS, Valle $\mathrm{D}$, eds. The metabolic basis of inherited disease. 6 th ed. New York: McGraw-Hill, 1989:1807-42.

2 Kaback MM. Thermal fractionation of serum hexosaminidases: applications to heterozygote detection and diagnosis of TaySachs disease. In: Ginsberg V, ed. Methods in enzymology. Vol XXVIII. New York: Academic Press, 1972:862-7. 
3 Myerowitz R, Piekarz R, Neufeld E, Shows TB, Suzuki K. Human $\beta$-hexosaminidase $\alpha$-chain: coding sequence and homology with the $\beta$-chain. Proc Natl Acad Sci USA 1985;82:7830-4.

4 Proia RL, Soravia E. Organization of the gene encoding the human $\beta$-hexosaminidase $\alpha$-chain. $f$ Biol Chem 1987;262: 5677-81.

5 Neufeld EF. Natural history and inherited disorders of a lysosomal enzyme, $\beta$-hexosaminidase. $\mathcal{F}$ Biol Chem 1989;264: 10927-30.

6 Myerowitz R. Splice junction mutation in some Ashkenazi Jews with Tay-Sachs disease: evidence against a single defect within this ethnic group. Proc Natl Acad Sci USA 1988;85:3955-9.

7 Arpaia E, Dunbrille-Ross A, Maler T, et al. Identification of an altered splice site in Ashkenazi Tay-Sachs disease. Nature 1988;333:85-6.

8 Ohno K, Suzuki K. A splicing defect due to an exon-intron junctional mutation results in abnormal $\beta$-hexosaminidase $\alpha$ chain mRNAs in Ashkenazi Jewish patients with Tay-Sachs disease. Biochem Biophys Res Commun 1988;153:463-9.

9 Myerowitz R, Costigan FC. The major defect in Ashkenazi Jews with Tay-Sachs disease is an insertion in the gene for the $\alpha$ chain of $\beta$-hexosaminidase. $\mathcal{F}$ Biol Chem 1988;263:18587-9.

10 Triggs-Raine BL, Feigenbaum ASJ, Natowicz M, et al. Screening for carriers of Tay-Sachs disease among Ashkenazi Jews. A comparison of DNA-based and enzyme-based tests. $N$ Engl $\mathcal{F}$ Med 1990;323:6-12.
11 Navon R, Proia RL. The mutations in Ashkenazi Jews with adult $G_{M 2}$ gangliosidosis, the adult form of Tay-Sachs disease. Science 1989;243:1471-4.

12 Paw B, Kaback MM, Neufeld EF. Molecular basis of adult-onset and chronic $\mathbf{G}_{\mathrm{M}}$ gangliosidosis in patients of Ashkenazi Jewish origin: substitution of serine for glycine at position 269 of the $\alpha$ subunit of $\beta$-hexosaminidase. Proc Natl Acad Sci USA 1989;86: 2413-7.

13 Landels EC, Ellis IH, Bobrow M, Fensom AH. Tay-Sachs disease heterozygote detection: use of a centrifugal analyser for automation of hexosaminidase assays with two different artificial substrates. F Med Genet 1991;28:101-9.

14 Saiki RK, Gelfand DH, Stoffel S, et al. Primer-directed enzymatic amplification of DNA with a thermostable DNA polymerase. Science 1988;239:487-91.

15 Roberts RG, Montandon AJ, Bobrow M, Bentley DR. Detection of novel genetic markers by mismatch analysis. Nucleic Acids Res 1989;17:5961-71.

16 Greenberg DA, Kaback MM. Estimation of the frequency of hexosaminidase variant alleles in the American Jewish population. Am ₹ Hum Genet 1982;34:444-51.

17 Kawasaki ES. Sample preparation from blood, cells, and other fluids. In: Innis MA, Gelfand DH, Sninsky JJ, White TJ, eds. PCR protocols. A guide to methods and applications. San Diego: Academic Press, 1990:146-52. 